\title{
5 Bodies and gender: entertaining literature
}

\section{A popular topic}

Cultural, artistic, and literary text production about Jews increased throughout the nineteenth century, in line with the general increase in the number of books being printed. Jews appeared in various shapes and functions in literary, satirical, and educational texts, which did not exist independently from the distinctly anti-Jewish political, theological, and legal discourse which aimed at preventing Emancipation for most of the century. For most readers - and theatre audiences - the Jewish figures personified and staged something they usually did not know as real people but as an abstract threat discussed in newspaper articles, sermons, and books. Within this framework, even those texts which do not bear distinctly antisemitic features played a background role of "creating a problem": Jews were much more present in writings than they ever were in real life, and a Swedish, mainly urban, public became used to seeing Jews as a distinctive group which was constantly being debated. On the theatre stage, Jews were usually people to laugh at.

Both Jewish and non-Jewish authors were present in the vast field of entertaining literature, most of the former translated from German. While a thorough investigation of the differences between Jewish and non-Jewish perspectives on, for example, the culture of Orthodox Jews in Galicia would be important for questions of style, self-representation, and the situation of Jews in the German lands and the Habsburg Empire, these differences were not particularly relevant in Sweden. It is doubtful whether Swedish readers knew that Leopold von Sacher-Masoch was Christian, while Karl-Emil Franzos was Jewish, when both described an East European Jewish culture which in Swedish newspaper articles had already been presented as utterly foreign, filthy, and outdated. The following short overview of literary texts with Jewish themes will show that regardless of the intention and origin of the authors, Jews were considered an interesting topic in nineteenth-century Sweden, and that most of the Jewish figures in operas, plays, and novels were portrayed stereotypically: angry and strict fathers, beautiful and silent daughters, greedy moneylenders, outwitted businessmen.

As early as 1801, a first edition of Richard Cumberland's play was published in a loose Swedish translation. Juden. Komedi i 5 akter was staged numerous times in the nineteenth century. The play had already been successful in England, where the text originated, and was equally popular in its Swedish translation; though mainly on the stage, as the first edition of the text was not followed by subsequent editions. In the German lands, one of the popular actors interpret-

Ә OpenAccess. (C) $2022 \mathrm{He}$, published by De Gruyter. (cc) BY-NC-ND This work is licensed under the Creative Commons Attribution-NonCommercial-NoDerivatives 4.0 International License. 
ing the main character in Cumberland's play was Albert Wurm. He also played the Jewish character Jacob in Karl Borromäus Sessa's Unser Verkehr, a reaction against the Prussian Edict of Emancipation in 1812, in which Jews are portrayed as a collectivity incapable of change, driven by greed and selfishness, situated in the ghetto - which Sessa's Jews are not able to leave, partly due to their inability to acculturate. The play led to a controversy in Berlin in 1815, when Israel Jakobsohn intervened with Chancellor Hardenberg and had the performance forbidden due to its obviously hostile depiction of Jews. ${ }^{230}$ This play was also translated and staged in Sweden under the title Spekulanterne, eller: Hoben se nix zu schachern?231 - already in the title alluding to the perceived "Jewish" practice of haggling and to the immigrants' language and accents. The controversy was also transmitted to Sweden, when Albert Wurm's account of the events leading to the censorship of the play and its later adaptations and staging was published under the title Judisk hämd (sic). ${ }^{232}$ Wurm had written this text as a complaint about how "the Jews" had destroyed his career and reputation just because they could not handle a little joke. The text, originally published as a serial in the newspaper Hamburgs Wächter in 1817, lists a number of threatening letters and other personal attacks on the actor, which he ascribes to Jews. Together with the title, it gives the impression that Jews are a serious threat, alluding to the stereotype of the Jewish thirst for vengeance. The Swedish preface explicitly describes the text as

en stark varning för hvarje Christen, att icke såra den Judiska nationens fåfänga, men hvilken varning man icke dess mindre är nog öfverdådig att trottsa medelst utgifvandet af denna öfversättning.

(a strong warning for every Christian not to wound the pride of the Jewish nation, even though one is about to defy this warning at length by publishing this text, n. pag.)

The comedy Den pantsatte juden eller Moses uppståndelse ur kistan, originally English, also came out in 1817. It centres around the love story between Qvins and the Jewish woman Bathseba, who is portrayed just like the Jews in Spekulanterne: unsympathetic, greedy, and slightly stupid. ${ }^{233}$ Bathseba and her inherited

230 Monika Schmidt and Bjoern Weigel, "Unser Verkehr," in Handbuch des Antisemitismus: Judenfeindschaft in Geschichte und Gegenwart, vol. 7, ed. Wolfgang Benz (Berlin: De Gruyter Saur, 2014).

231 Karl Boromäus Sessa, Spekulanterne, eller: Hoben se nix zu schachern? Fars $i$ en akt. Öfversättning efter tredje original-upplagan af Unser Verkehr (Stockholm: A. Gadelius, 1817).

232 Albert Wurm, Judisk hämd (Stockholm: A. Gadelius, 1818).

233 Den pantsatte Juden, eller: Mosis:s uppståndelse ur kistan. Lustspel i 2 akter (Stockholm: Carl Nyberg, 1817). 
fortune are controlled by Moses, who is unwilling to let her marry a poor Christian, and who also intends to withhold her money. The priest Snowt devises a plan to make Moses pay 1,000 pounds, and this succeeds with the help of a complicated trial. Bathseba never actually appears on stage. Her guardian Moses, on the other hand, is the prototype of the dishonest, avaricious moneylender who is outwitted by his own greed. The humorous part of the play was supplied by the malicious Moses and the lawyers at the trial. The characters provide the reader with an example of the "bad Jew," Moses, with all the familiar features of greed and envy. Bathseba, on the other hand, is presented as a "good Jew": willing to convert out of love for a poor Christian, oppressed, beautiful, and silent. Besides being an acceptable Jew, she is also an example of a "good woman" in general, and thus her gender performance outweighs her religious identity.

Wilhelm Hauff's novel Jud Süss was translated and printed twice: in 1828 as Juden Süss, först schackrare, sedan minister, sist hängd. Sann historia, tecknad efter naturen (Jud Süss, first haggler, then minister, hanged in the end. True story, faithful to events) ${ }^{234}$ and one year earlier, the same year as the German original, under the title Judeväldets undergång $i$ upplysningens århundrade (The downfall of Jewish dominion in the Age of Enlightenment). ${ }^{235}$ Neither of these published works mentioned the German author. The title of the second edition in particular emphasizes the novel's being a metaphor for Jewish progress followed by self-destruction. The antisemitic potential of this literary adaptation of the biography of Joseph Süß Oppenheimer is something well known, as is the way in which it was later received by German National Socialism. Even here, the "bad Jew" is juxtaposed to a "good woman," Joseph's sister Lea, the love interest of the poor Christian Gustav Lanbek. This novel ends with the death of both good and bad Jews: Joseph is executed, Lea kills herself over his death and the unhappy affair with Gustav, who in turn becomes depressive.

These two editions of the same novel were the first texts by Wilhelm Hauff to be translated into Swedish, but in the following decades, even his romantic fairy tales became popular and were translated and printed several times. Jud Süß, printed in Swedish as a book, provided Swedish readers with "insight" into the seemingly disastrous influence Jews had on the royal courts of Europe. The title suggesting the downfall of "Jewish dominance" as a result of the En-

234 [Wilhelm Hauff], Juden Süss, först schackrare, sedan minister, sist hängd. Sann historia, tecknad efter naturen (Stockholm, Elméns och Granbergs tryckeri, 1828).

235 [Wilhelm Hauff], Judeväldets undergång i upplysningens århundrade, Öfversättning (Stockholm: Marquardska boktryckeriet, 1827). 
lightenment actually ran contrary to Hauff's intentions and his epilogue to his novel, in which he criticized the despotic action of the Duke who had Oppenheimer executed and advocated for a more enlightened form of government and legislation.

Two years later, an anonymous collection of jokes and short stories, Judarne $i$ all sin glans och härlighet, ${ }^{236}$ seems to have enjoyed a certain popularity. Compared to most of the other texts discussed here, it appeared in a fancier and better quality edition, with coloured plates inserted depicting scenes from the stories. A deeply ironic introduction, as well as the subtitle, refers to Jews as "gold people" (guldmänniskor). It implicitly compares a dialogue with Jews to "talking to dogs and donkeys" (p. 1), repeats the accusation that betraying Christians is based on Jewish religious laws (p. 2), and generally constructs Jews as a collective Other with distinct characteristics such as law-centredness, greediness, and crude cunning, without any aptitude for deeper thought. In the stories themselves, Jews are constructed as a group of foreigners who all speak a German-Yiddish-Swedish pidgin. Many of the stories have as their themes domestic violence within Jewish families, violence inflicted on Jews for no apparent reason, and, once again, business practices. The label "Jewishness" establishes a certain tone of ridiculousness, which does not come from anything specific that the characters do but from the fact that they are Jewish - many jokes would work just as well without the label "Jewish," but the book makes a point of repeating it. For example, story 46, about two Jewish girls who talk about what to wear to a masquerade, and a Christian office clerk who comments with disdain on their choice of attire - the religious difference adds a dimension to the story that has absolutely no reference in the conversation itself, which would have worked even without it. This provides a clue as to the origins of at least part of the text: probably these were commonly known or collected jokes and stories, which were spruced up by adding Jewishness or religious difference to the characters, with the result that the Jews are always the butt of the joke.

In other stories, either the Jewish religion or imagined Jewish characteristics are the main ingredients of the joke; these might include circumcision, consumption of pork, the rabbi's study habits, or the "Jewish odour" - or simply an abundant greed for money.

There is no explicit reference made to the specific legal circumstances of Swedish Jews or Sweden in general, the few actual places named are from all

236 Anonymous, Judarne i all sin glans och härlighet, eller en utvald samling af 263 lustiga anekdoter, infall och märkvärdiga historier om dessa guldmenniskor. Med 6 kolorerade planscher (Stockholm: Elméns and Granbergs, 1830). 
over Europe: Munich, Vienna, London, Carlsbad, Poland. The range of professions and work situations the characters are situated in - stock trade, horse trade, teacher, even military service and unemployment - are much more varied than the demographics of the Swedish Jewish community, and they reflect a European post-Emancipation situation in which Jews theoretically had access to all areas of society.

Gender relations are portrayed in several stories about Jewish couples, most of them revolving around the wife's real or suspected marital infidelity, or their stupidity and nastiness. Male Jews are accused of polygamy because they "wanted to search until they found a good wife" (p. 173), or else they beat their wives regularly. Flirtation between Jews and Christians always ends badly.

The development and use of antisemitic images in Swedish media has attracted some interest in historical scholarship. ${ }^{237}$ Focusing on the visual imagery, Lars M. Andersson does not see this book as openly antisemitic, since the Jewish characters lack the already established visual markers for "Jewishness" 238 - a somewhat incomplete assessment, since what is lacking in the images is abundantly represented in the texts. Indeed, there are only six images illustrating 184 pages of text, almost all of which show "established markers of Jewishness." Published in 1830, this manifesto of hatred established a very small group of immigrants as culturally different, as objects of ridicule and disgust, and in so doing also suggested that the men, women, and children of this group shared an unchangeable essence or nature.

Judarne $i$ all sin glans och härlighet is a malicious mixture of different stereotypes, portraying a religious minority present in various European countries as a group of greedy, immoral, ridiculous, and stupid men and women. One needs to take into account that joking about minorities was probably widely accepted in

237 Lena Johannesson, “'Schene Rariteten’: Antisemitisk bildagitation i svensk rabulistpress 1845-1860," in Judiskt liv i Norden, ed. Gunnar Broberg, Harald Runblom, and Mattias Tydén (Uppsala: Acta Universitatis Upsaliensis, 1988).

238 "Kurz nach der Fehde im Jahr 1830 erschien 'Judarne i all sin glans och härlighet eller en utvald samling af 263 lustiga Anekdoter, Infall och märkvärdiga Historier om dessa Guld-Menniskor' [Die Juden in all ihrer Herrlichkeit und Macht oder Eine ungewöhnliche Sammlung von 263 unterhaltsamen Anekdoten, Wunderlichkeiten und sonderbaren Geschichten über diese Gold-Menschen]. Es handelt sich um eine Zusammenstellung von Geschichten über Juden, viele davon sind jedoch keineswegs pejorativ. Es enthält sechs großformatige farbige Abbildungen, die 'Juden' in mehr oder weniger verfänglichen Situationen darstellen. Vier der sechs karikierten männlichen Juden haben große Hakennasen und alle tragen Bärte. Aber weder ihre physische Erscheinung im Allgemeinen - alle besitzen 'normale' Statur und Größe - noch ihre Kleidung unterscheidet sie von Nicht-Juden.” Lars M. Andersson, “Schwedische Karikaturen,” in Handbuch des Antisemitismus: Judenfeindschaft in Geschichte und Gegenwart, vol. 7, 439. 


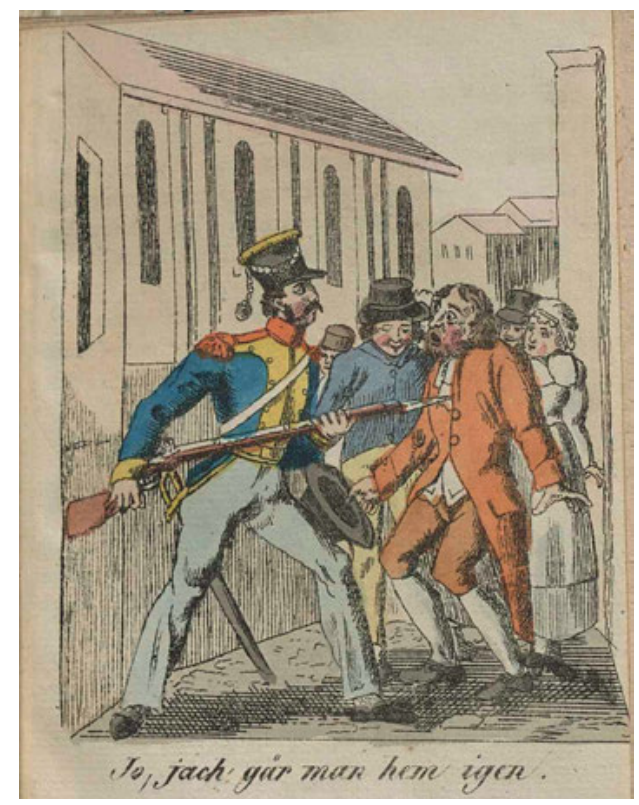

Fig. 7: Illustration from Judarne i all sin glans och härlighet (Kungliga biblioteket, Stockholm).

nineteenth-century Sweden, but the book contains a specific melding of religious prejudice, racial constructions of Jewishness, and ridicule created within its stories and framed with references to religious difference. Various possibilities for Othering are employed and create a collective, yet varied, image of Jews as religiously, culturally, and essentially different. Conversion does not appear in the text. The variety of professions, places, and situations the Jews are situated in create a sense of their omnipresence.

Some of these texts had nothing special to say about Jews besides their title. For example, Den spökande judinnan, a three-page leaflet printed in Stockholm in 1819, was translated from a German collection of ghost stories and features a Jewish woman prominently in its title, though less prominently in the text itself. The supposed ghost of a gruesomely murdered Jewish woman, which greatly alarms a Prussian cavalry officer and his horse one night near Frisack in Mark Brandenburg, appears on closer examination to merely be a white tree trunk. ${ }^{239}$ There is nothing particularly Jewish about the figure of the ghost; she

239 Anonymous, Den spökande judinnan (Stockholm: Elmén and Granberg, 1819). Cf. Samuel 
is simply referred to as "judinna," becomes the victim of a crime, and is then a ghost. One can only speculate as to whether and why a Jewish ghost was supposed to be more or less scary than a Christian ghost. The text is one of several examples where the Jewishness of a character is mentioned prominently in the title but plays no significant role in the text itself.

Dulech, a story published at least twice, in 1772 and 1826, is slightly different. The subtitle promises a "story, translated from the Jews' Talmud"; since the Talmud already played a prominent role in theological and political polemics, potential readers might have expected something dark and twisted - not quite what the text provides. Taking place in the city of "Susan" (Susa) in Persia during the reign of King Ahasverus, it bears the distinctive features of an Orientalist fairy tale. A rich old man, Rabner Samsson, sees a beautiful young woman dancing in an establishment called "Förtjusares Slott" (the castle of the enchanting), falls in love with her, and has a servant offer her large quantities of money if she would allow him to unclasp the band of gold and silver with which her stockings were held up. The girl, Dulech, accepts a small portion of the gold as a present but asks Rabner to wait a couple of days before she gives him her answer. She then sends a letter to her beloved partner Seva - Dulech is described as his "frilla" (concubine or second wife), and it later turns out that they already have a baby together - who is travelling, and asks his advice. Seva hurries home and uses various means, including showing her their child, to persuade Dulech to return the gold. The rest is a slightly pornographic description of how the two lovers celebrate their reunion, including detailed meditations on Dulech's naked breasts.

The text exists in a clearly "Jewish" framework, by purporting to be translated from the Talmud. Dulech's name also suggests that she is Jewish, and Ahasverus, even though the Bible describes him as a king who wanted to have all the Jews in Persia killed, was obviously the name associated with the Wandering Jew in Sweden at the time. Other names appearing in the story, such as Thamar (Dulech's servant), Seva, and Rabner, also suggest the Jewishness of the characters, despite the Persian setting. Orientalist ideas and stereotypes merge in the story, particularly regarding gender relations. The fact that Dulech seems to have forgotten her son with Seva and that she dances in a brothel-like house for the amusement of old men suggests a severe violation of Lutheran family relations. The exotic family situation is rendered intelligible by the Swedish word "frilla,"

Christoph Wagener, Fünfunddreissigste Erzählung: Die spukende Jüdin bey Frisack. Die Gespenster. Kurze Erzählungen aus dem Reiche der Wahrheit, 2. Band (Berlin: F. Maurer, 1798), 260-65. The story is an excerpt, translated from the collection "Die Gespenster" by Samuel Christoph Wagener, a teacher and Lutheran priest in Brandenburg. 
which can refer to a woman who has a sexual relationship with a man without being married, or a concubine, or simply a sex worker. At the very end, the text suggests that the rich man Rabner eventually got his way and made Dulech betray her lover - "this is written in the Girls' chronicle, by those who were dancing and singing in Förtjusarens palats in Susa."

Much later in the century, the satirical dialogue Judarnes funderingar, pro eller contra ${ }^{240}$ was very concretely situated in the juridical situation of the year 1838, when the king tried to establish civil Emancipation but was forced to revoke the edict after only a few weeks. It lists the different areas of trade and settlement which might be opened up to Jews, discussing the possibilities and dangers. For example, the danger is noted that Jews might be murdered when trying to move to smaller towns and villages. The general conclusion leans toward Emancipation being bad for Jews as well, since it would aggravate hostility towards them, and advises them to voluntarily remain within the restricted areas of trade and settlement. The text is structured by the dialogue between several Jewish siblings and their "Mutter Rachel," who starts by lamenting her husband's death and quoting his prophecy:

Redan den tiden då fråga uppstod att jaga oss Judar från Landet, sade han: "Vi stanna qvar; Sverige bör blifvä vårt rätta fädernesland, och Judas, min son Judas, skall blifva en stor man.”

(Already at the time when the question came up to expulse us Jews from the Land, he said: We are staying, Sweden should become our true fatherland, and Judas, my son Judas, shall become a big man, p. 1).

Her children Susanna, Aron, Benjamin, Moses, Jacob, Isac, Isacsan, Judith, and Judas discuss the different choices and possibilities they believe they will have after the Emancipation process is complete: one wants to become a high-ranking soldier, one a factory owner, one wants to move to a small town and become a peddler. As the other siblings are sceptical about their chances, they decide to stay home and wait to see how these endeavours turn out. It is not mother Rachel who is most prominent in the dialogue, but sister Susanna, whose wisdom represents an enlightened, humanist point of view on people's equal rights and everyone's moral obligations towards society. The text's intention is difficult to grasp. It lists complications, hostility, and problems that Jews will encounter in Sweden despite their newly granted civil rights. The general tone is not hos-

240 Anonymous, Judarnes funderingar, pro et contra, eller Mutter Rachels samtal med sina barn: Häfte 1 och 2 (Stockholm: A. G. Hellsten, 1838). 
tile, even though the impression remains that they themselves are to blame for the anticipated problems, due to their collective behaviour.

In 1883, the collection of novels Der Juden-Raphael, by Leopold von SacherMasoch, ${ }^{241}$ came out in Swedish translation, and in 1878, Karl Emil Franzos's novels Die Juden von Barnow ${ }^{242}$ and Judinnan were both translated anonymously. Both books represent views on the Eastern European Jewish culture of the Pale of Settlement in Galicia, Poland, and the Russian districts, and have been labelled "ghetto narratives."243

Several popular publications contained stories revolving around Jewish characters or themes; these increased noticeably in quantity towards the end of the century. In these stories, unlike most other text genres, female Jewish characters played a central role. Between 1851 and 1900, no less than eleven books bore the title "The Jewess" (Judinnan), by both Jewish and non-Jewish authors and ranging from high literature to dime novels. Not all were clearly anti-Jewish, but the sheer number of titles testifies to a somewhat stereotypical focus on the interrelation of Jewish and gendered themes.

Two editions of Fromental Halévy's opera La Juive ${ }^{244}$ and Joseph Méry's Judinnan $i$ Vatikanen were translated from French. The latter was a blunt presentation of religious antisemitism, deicide accusations, and the allegedly malicious character of Jews; it had been sanctioned by the Catholic Church. ${ }^{245}$

Jenny Maria Ödmann's ${ }^{246}$ and Agnes Lagerhjelm's ${ }^{247}$ two works, each titled Judinnan, were Swedish originals (Lagerhjelm's was also published under her initials A. L.). Philip Galen's Jane, die Jüdin (three volumes) ${ }^{248}$ was translated from German and was also published under his real name Philip Lange and "loosely translated by Blot-Sven." Heinrich Marschner's opera Der Templer und die

241 Leopold von Sacher-Masoch, Jud-Raphael (Stockholm: Skoglund, 1883).

242 Karl Emil Franzos, Judarne i Barnow (Stockholm: Seelig, 1878).

243 On this complex subject, see Francisca Solomon, Blicke auf das galizische Judentum: Haskala, Assimilation und Zionismus bei Nathan Samuely, Karl Emil Franzos und Saul Raphael Landau, Im Spiegel der Literatur 7 (Wien: Lit, 2012).

244 Fromental Halévy, Judinnan (Stockholm: Alb. Bonnier, 1866).

245 Joseph Méry, Judinnan i Vatikanen eller Amor och Roma (Stockholm: Hierta, 1851). See William Brustein, Roots of Hate: Anti-Semitism in Europe before the Holocaust (Cambridge: Cambridge University Press, 2003), 60-61.

246 Jenny Maria Ödmann, Judinnan (Mariefred: Öhman, 1867). She also wrote Rachel and Ruth and a large number of other novels, most of them as serials in her husband's newspaper Fäderneslandet. See https://litteraturbanken.se/författare/ÖdmannJM.

247 Agnes Lagerhjelm, Judinnan (Stockholm: Lundholm, 1870).

248 Philipp Lange, Judinnan (Stockholm: Wall, 1877). 
Jüdin ${ }^{249}$ and Karl Emil Franzos's ghetto novel Die Jüdin ${ }^{250}$ were also translated from German. A comparable number of novels and plays were simply titled "The Jew": Cumberland's play; from German there was Carl Spindler's Juden: tysk sedemålning från första hälften af femtonde århundradet (in three volumes) ${ }^{251}$ and Carl Gottlieb Samuel Heun's (Carl Heuer) Den holländske juden; ${ }^{252}$ from Danish, Thomasine Gyllembourgh's Berättelser: Juden; ${ }^{253}$ from Russian, Ivan Turgenev's collection of novels Två vänner, Juden and Min första kärlek; ${ }^{254}$ in Danish and Swedish, Anna Maria Schunck's Juden: sann händelse versifierad. ${ }^{255}$ There was also Birger Mörner's Juda ${ }^{256}$ and Cederqvist's Judens dotter. ${ }^{257}$

Many of these books would not be classified as high literature. The Swedish originals by Cederqvist, Lagerhjelm, and Ödmann were cheap serials, published as booklets of a few pages each and coming out every few weeks. They deal with young, tragic love, the impossibility of interreligious relations, and conversion as the ultimate form of integration, which thereby represents a happy ending. Cederberg's book appeared as a series, but finished at number 14 instead of the 26 which had been promised. Lagerhjelm's novel adheres closely to the formula of the early modern conversion stories mentioned above: young Bertha grows up in a rich Jewish home, longs for conversion, her father is against it, she turns down Jewish Ferdinand's proposal, her father falls sick, she converts and has him converted as well, and in the end she marries Ferdinand (who has also converted). The number of conversions in this romantic series borders on the ridiculous.

Philip Galen's Jane is a Jew from Sweden, who ends up in a happy marriage with Reinhold, a Christian, and they never tell anyone that she used to be Jewish. In Cederqvist's Judens dotter, Nathan is cursed by a "gypsy" woman he had once

249 Heinrich Marschner, Tempelherren och Judinnan (Göteborg, 1865).

250 Karl Emil Franzos, Judinnan (Stockholm: Ad. Johnson, 1891).

251 Carl Spindler, Juden: tysk sedemålning från första hälften af femtonde århundradet, 3 vols (Stockholm: Hjerta, 1834).

252 Carl Gottlieb Samuel Heun, Kortare berättelser och lustiga äfventyr, af Clauren. Innehållande: Pistol-lektionen, Resan till lägret, Utseendet bedrager ofta, Korfbalen, Paulowna, Den holländska juden, m.fl. (Stockholm: Ecksteinska tryckeriet, 1824).

253 Thomasine Gyllembourg, Nya berättelser. Af författaren till en "hværdags-historie”. Utgifna af J. F. Heiberg. Tredje delen: Juden. Hvitkappan (Stockholm: Hjerta, 1837).

254 Ivan Turgenjef, Två vänner; Juden; Min första kärlek. Från ryskan öfversatta af - K (Stockholm: Norstedt, 1887).

255 Anna Maria Schunck, Juden: sann händelse versifierad (Malmö: Cronholm, 1862).

256 Birger Mörner, Juda. Dramatisk dikt in en actus (Göteborg: T. Hedlund, 1888).

257 August Cederqvist, Judens dotter: Berättelse / af Curre (Göteborg: J. F. Richters bokhandel, 1879). 
kicked, but surprisingly all ends well for him and his daughter Rakel, after yet another unhappy arranged marriage.

\section{Anti-Jewish medievalism}

The European Middle Ages were, at least after the First Crusade, admittedly not a happy period for the Jewish minority. Executions and waves of pogroms serve as a background to descriptions of Jewish-Christian relations as naturally violent.

Carl Spindler's monumental novel (appearing in Sweden in 1834) deals with Jewish-Christian relations in 1414, in the period of the Councils of Constance and Basel. Hostility, violence, and restrictions on Jewish mobility, as well as the Jews in Frankfurt having to wear a yellow ring on their clothes, are all presented as the normal form of Jewish-Christian relations. His Jew is a stereotypically old, ugly, “Eastern”-looking moneylender, whose daughter Esther is beautiful and pure and is condemned to marry another Jew according to both the cruel laws of her people and the cruel wishes of her father. Halévy's opera Judinnan, published in Sweden in 1866, also takes place in Constance in 1414; the story revolves round the relation between Eleazar, his daughter Rachel, and her lover Leopold - Eleazar prefers to see his daughter executed and to die with her, rather than see her convert. In the end, both are boiled to death in a cauldron. In Fromental Halévy's opera, neither male Jews nor Christians are obviously sympathetic, only the female protagonist Rachel is portrayed as innocent - she dies in the end, and her father reveals that she was not an actual Jew but a Christian child he had saved and adopted.

Birger Mörner was a duke, traveller, diplomat, and author. His works include travel reports from Turkey and the Mediterranean, historical novels as well as poetry. As such, he belonged to the upper class and his writings enjoyed a certain popularity and discursive weight. Juden is a play in one act, featuring a Jewish family: "the Jew," his daughter Ruth, an old woman, and "the foreigner." It takes place, as many medieval pogroms actually did, on Christmas Eve, shortly after the Black Death in 1350. It is the old story of a cruel father - the absent mother having been killed by Christians. The foreigner turns out to be the couple's firstborn daughter, who married a Christian and was disowned by her father as a result. The child's father died of the plague and the disowned mother killed her baby. The cruel father does not want her to meet her younger sister Ruth, not even after a final encounter with the daughter in which she begs for forgiveness.

Besides the unsympathetic father, the story takes on an anti-Jewish meaning by its framing of the daughter's gruesome fate as well as the repeated references to anti-Jewish pogroms: it is the Jews' own fault. The old woman explains to Ruth 
why she is not allowed to go into the city centre: "Vi har mördat, se I, mördat." (We have killed, you see, killed, p. 15). When Ruth's father comes home bleeding, she draws on her new knowledge: "Juda slog Moses, nur slår kristfolket oss." (Juda beat Moses, now the Christian people are beating us, p. 18).

In all of these cases, the medieval setting provides an opportunity to present violence towards Jews - pogroms, executions, and violations - as righteous responses to the deicide. Centring the religious difference and taking the deicide accusation at face value, extremely cruel and horrible stories fulfil entertaining purposes while also teaching the Christians a valuable lesson: it is the Christians' right to kill Jews, most visibly and bluntly in the Middle Ages, but today as well.

\section{The collective Jew receives a gender}

There are a surprising number of belletristic texts in the corpus which not only had Jewish characters but which explicitly referred to these in the title. These contribute to a different part of the archive than political pamphlets, but just like the medieval legends and the conversion stories, they add to the general "knowledge" about Jews. There were operas, plays, and novels, which probably belonged to the area of high culture or literature, but there were also many dime novels, serials, and booklet series depicting romantic but tragic stories, which were probably read by a different public than the people who attended the opera and read the libretti. It is difficult to get a general picture of what Swedes took from all of these books and plays - did the occasional Jewish author and his self-perception of the Galician Shtetl culture, or the occasional didactic legend portraying a compassionate Jew, change the general perception of "Jews"?

Generally speaking, the representation of Jews in these works can be compared to today's representation of queer and trans people in movies - or, for that matter, of strong, intelligent women in Henrik Ibsen's plays. They can be either aggressive and dangerous or adorable and tragic, but they can never be happy - not as long as they hold on to their nature. For the Jews in Swedish literature, conversion or death are the only possible outcomes, with conversion being portrayed as a happy ending. The many conversion stories presented as romances, in operas or in plays, repeat the narrative patterns of medieval and early modern conversion stories: children touched by grace and wanting to convert, cruel parents, sickness or violent deaths stipulating redemption where conversion did not happen.

In contrast to all the other themes and texts, it is in the novels and plays that Jews have more than one gender. While the collective Jew in the Swedish imag- 
ination is implicitly male, given that his business activities, circumcision, and political activities point towards male spheres of action in the bourgeois societies of the nineteenth century, literary products also know and depict female Jews, even in prominent and leading roles in the texts. The portrayal of Jewish men and women in literary texts followed popular stereotypes, which were in turn informed by the collective Jews from theological, political, and economic discourses, and yet here they were not a collectivity but individuals. This opened the possibility not only for different genders but also for individual character traits - even though this potential was certainly not explored as much as it could have been. The male characters are most often portrayed with at least some of the features of the collective Jew - greed, nastiness, ugliness, etc. Female Jews, on the other hand, seem to not participate in or share the collective features to the same extent as the males do - they do not deal with money, they can be either ugly or seductive and pretty, and they can be intelligent and well educated without the crude cunning of the male (collective) Jew.

It is important to note that the plays published do not represent the entirety of plays with central or peripheral Jewish figures that were staged, and that the printed texts followed different logics and patterns of text consumption than the plays. Clemens Räthel has written extensively about the most important Swedish plays with Jewish characters and how they were cast and interpreted. A much less hostile picture emerges from this than from the printed texts considered in context with the rest of the text production on the "Jewish question." Räthel, looking not only at the staged plays but also at the reaction of the public and the Jewish communities to these, has analysed the potential for self-empowerment in these portrayals, revealing a multi-layered relation between inclusion, ridicule, and visibility. ${ }^{258}$ The situation with the printed texts is somewhat different, first, because the performative aspect is missing, and second, because popularity on the stage does not necessarily coincide with popularity in print. The paper versions of plays with Jewish characters are thus, again, only one aspect of the entire discourse. Furthermore, they could be supplemented with other texts supporting a rather negative reading of the Jewish figures. Love stories between Christian men and Jewish women, and the related troubles and misfortunes that befall both genders, are a prominent theme, as is an ethnographic view of Eastern European Jewish culture. They are not necessarily antisemitic per se, but must be read in the context of the rising antisemitism in Germany and Sweden at the time. While Franzos was himself Jewish, von Sacher-Masoch

258 Clemens Räthel, Wieviel Bart darf sein? Jüdische Figuren im skandinavischen Theater (Tübingen: Narr Francke Attempto, 2016). 
was a cosmopolitan Christian inhabitant of the Habsburg Empire who was born in Lemberg, studied in Prague, and lived in Graz. Both authors took political stands condemning antisemitism but also contributed to mechanisms of Othering and alterity by portraying Eastern European Jewish culture as foreign, exotic, and from a different place and time - while it was immigrants from that region who were the main targets of Swedish antisemitism, both in propaganda and in terms of immigration policies, as Carl Henrik Carlsson has shown. ${ }^{259}$

Things are not going great in the Jewish family, even though their sex life seems to be great - as described in Dulech, in Judarne in all sin glans och härlighet, Den pantsatte Juden, and other works. In stories with only Jewish figures, the gender roles conform to the expectations of nineteenth-century bourgeois society. Seva, the traveller with the beautiful concubine at home, sees his masculinity and claim of ownership of Dulech's body restored. Dulech is situated in the polygamous world of sex workers, reminiscent of a harem - a mysterious female space where the women even have their own secret chronicle in which the end of her story is preserved, hidden from the Swedish readers' eyes. Both Dulech and Thamar are beautiful, fairly independent women, who need to be reminded of their moral and family obligations. Thamar is loyal to Dulech and no one else. The men in the story are driven by their desire (Rabner and Seva) or simply do what they are told (their servants), and everything they do in the story revolves around Dulech. The guilt for her moral flexibility is entirely put on her, not on Rabner who made the offer - and this might be another detail that makes the text more intelligible to Swedish readers, since blaming women for male desire and abuse is deeply rooted in Western culture.

Portraying Jewish families and couples in a cultural framework far removed from Protestant Sweden creates an opportunity for multiple and varied processes of Othering in which, in contrast to the other text genres, religion does not play a major role. The Jewish characters do not eat kashrut, they do not observe the Sabbath, and, generally, their Jewish religion is not established in a performative way. It is the Otherness that is established performatively, imagined according to the characteristics of the collective Jew: a "Jewish" language, a common striving for integration into Swedish society as well as its impossibility, and a hunger for power and money.

259 Carlsson, Medborgarskap och diskriminering. 


\section{Pro-Jewish contributions}

Besides a number of direct responses to anti-Jewish texts, independent voices speaking up unprovoked for Jewish rights were rare, whether from the Jewish minority itself or from Christian authors.

Probably the most prominent pro-Jewish contribution came from Erik Magnus Pontin (1819-1852), a conservative publicist in service to the crown. ${ }^{260}$ In 1847, he published a political treatise, Judarnes emancipation ur svensk synpunkt betraktad, in which he summarized public opinion and government actions regarding the Jewish question and also described the, in his view positive, examples of Emancipation in other European countries. In his summary of the status quo, he mentions the petition sent from the Jewish community to the king on 22 March, 1847, which requested complete equality with other Swedish citizens. Pontin quotes from the subsequent consultations with communal authorities in the regions where Jewish communities lived (not unlike the situation in 1838). The landshövdingeämbete from Blekinge argued that the time was not right for such a reform:

Ehuru den upplystare delen av nationen i allmänhet sannolikt inser den sökta concessionens öfverenstämmelse med tidsandans fordringar och civilisationens framskridande, mängden af Svenska folket likväl, i följd af dess tro på Evangelisk-Lutherska Lärans bekännande såsom oundgängligt villkor för ömsesidigt förtroende och redlighet, är så fästad vid uråldriga begrepp om nödvändigheten af enahanda troslära för statens embetsmän....

(Even though the more enlightened part of the nation obviously realizes that the concession requested accords with the needs of the spirit of the time and with the advance of civilization, due to their belief that the evangelical-Lutheran religion is a necessary precondition for mutual trust and morality, most Swedes remain bound to the antiquated idea that state servants must share a common faith .... $)^{261}$

Pontin believed this statement to be a coward's excuse, blaming "the simple people" and their conservatism for one's own opposition to reform. Still, the ar-

260 Erik Magnus Konstans Pontin was a rather conservative author on political matters; for example, in 1848 he denounced the French Revolution in another book. Nevertheless, he was committed to the education of workers and was generally liberal on social matters. In addition to his work as a publicist and editor, he tried his hand, unsuccessfully, as a literary writer. He also wrote another text regarding Jewish emancipation, in 1845: "Förtjena judarne politiska rättigheter?" "Pontin. Erik Magnus Konstans,” in Nordisk Familjebok: Konversationslexikon och Realencyclopedi, vol. 21 (Stockholm: Nordisk familjeboks förlag, 1915).

261 Erik M. Pontin, Judarnes emancipation ur svensk synpunkt betraktad (Stockholm: Lundberg \& Comp., 1847-1848), 35. 
gument seems to have not been limited to this particular state employee, since even the authorities from Gothenburg rejected the planned reform with the argument of "the sanctity of the state religion" (Stats-Religionens helgd). Pontin also pointed out, in his summary of different statements by politicians regarding Emancipation, that Baron Sprengtporten, who already stood out in 1838 as a liberal-minded nobleman, was the first to note that a basic problem lay in the fact that Jews in Sweden were placed under the Board of Commercial Affairs, which had established the judereglemente in 1782. Sprengtporten argued that they instead belonged under the administration of general internal and political affairs, as limiting Jews to the role of merchants already implied a restriction of their civil rights. On 13 September, 1847, the Board of Commercial Affairs submitted a report detailing all the statements on the question received from throughout the country. Pontin also discussed the different estates' interests in the rejection of the Emancipation request (p. $43 \mathrm{ff}$.).

Surprisingly, Judarnas emancipation presents the question of Emancipation in opposition to liberal arguments and in line with the position of the Swedish king at the time. Prior to his first contribution, Förtjena judarne politiska rättigheter (1845), Pontin had mainly written plays and novels; in the political arena, he was socially liberal but politically conservative. The newspaper Morgonbladet, which he edited in 1850 and 1851, was suspected of being directly under the king's control and argued against liberal papers such as Aftonbladet. ${ }^{262}$ As many liberal voices in Sweden argued that the Emancipation decree in 1838 had been issued without the approval of the estates and imagined various connections between the king and the Jewish community - ranging from Jews having bribed the king, to the king himself being Jewish - the conservative position automatically defaulted to a more pro-Jewish position. This is a clear difference from the political situation in the German Empire, where those with liberal positions were typically also pro-Jewish or pro-Emancipation. It is interesting that Pontin explicitly argued against the need for a state religion, and as such against the need for religious homogeneity.

It has been mentioned previously that the neighbouring Nordic countries and their strategies and policies regarding Jewish Emancipation did not play a major role in the Swedish debate and print production. Norway, having recently gained independence from Sweden, was probably too much of a sore spot to be used as an example, even though the infamous jødeparagrafen in its first constitution appeared as an attractive political solution to many in Sweden as well. In 1842, however, the most prominent opponent of the Norwegian anti-Jewish pol-

262 “Magnus Erik Konstans Pontin,” in Nordisk familjebok, Uggleupplagan, vol. 21. 
icy, Henrik Wergeland, had one of his pamphlets translated, in which he advocated for the complete repeal of the paragraph in question. ${ }^{263}$

An anonymous author argued in 1862 in favour of the king's proposal, which was being debated at the time, to allow Jews and Christians to intermarry. It had previously been printed in the newspaper Dagligt Allahanda; while acknowledging the importance of religion in general, it also argued for the separation of Church and State. ${ }^{264}$

Many pro-Jewish contributions were translated from German, most but not all by authors belonging to the Jewish Reform movement in Prussia. One Protestant German text, Gerhard Friederich's Huru skola judarna förbättras?265 (1816), described Jews not as a monolithic group, but as being made up of different social classes. As a consequence, he called for measures of social and religious integration differentiated according to their economic situation. Theodor Mommsen's response to Treitschke during the Berliner Antisemitismusstreit was also translated, alongside the many anti-Jewish contributions from this dispute. ${ }^{266}$ The response of Swedish (and Danish) Jewish intellectuals to this event merits greater attention; as it was not published in book form, however, it does not appear in this corpus. ${ }^{267}$

In 1870, Associations-boktryckeriet in Stockholm printed a translation of Ludwig Philippson's book Haben die Juden wirklich Jesum gekreuzigt?268 This was a biblical-historical analysis comprised of several articles translated from the Allgemeine Zeitung des Judenthums, the central organ of liberal Judaism in Germany. Its main argument is that Jesus's conviction and execution by the

263 Henrik Wergeland, Judarne i deras närvarande ställning inom samhället, med afseende på deras emancipation; jemte förslaget till upphäfvande af $2 \S$, sista momentet, uti Norges grundlag (Stockholm: Bonnier, 1842). See also Nils-Petter Enstad, "Henrik Wergeland og 'Jødeparagrafen'," Idé 2 (2001): 14-15.

264 Anonymous, I anledning af lagförslaget om äktenskap mellan kristna och judar (Stockholm: N. Marcus, 1862).

265 Gerhard Friederich, Huru skola judarna förbättras? Ett ord till behjertande för sanningens vänner (Stockholm: A. Gadelius, 1818).

266 Matthias Jacob Schleiden and Theodor Mommsen, De tyske stormännen Matthias Jakob Schleidens och Theodor Mommsens röst $i$ judefrågan (Uppsala: E. Edquist, 1881).

267 See Christoph Leiska, “Das Geschrei des 'Herrn von Germanenstolz’: Dänisch-jüdische Intellektuelle und der moderne Antisemitismus im deutschen Kaiserreich," in Einspruch und Abwehr: Die Reaktion des europäischen Judentums auf die Entstehung des Antisemitismus; (18791914), Jahrbuch zur Geschichte und Wirkung des Holocaust 2010, ed. Ulrich Wyrwa (Frankfurt am Main: Campus-Verlag, 2010).

268 Ludwig Philippson, Hafva judarne verkligen korsfäst Jesus? (Stockholm: Associationsboktryckeri, 1870). 
Roman authorities followed an established procedure for Jews who claimed to be the messiah and that this was in order to pre-empt popular movements. Thus, the text argues against the obviously still current accusations of deicide, which had been informing anti-Jewish thought for centuries. Philippson, a prominent and very productive rabbi and author who lived in Magdeburg and was editor of the Allgemeine Zeitung des Judentums, also had two of his novels published in Sweden at the very end of the century.

In terms of political interventions in the public sphere, printed contributions by members of the Jewish community were rare and were usually published anonymously. This was true of the responses to anti-Jewish texts, and it also applies to a collection of statements from German (Prussian) professionals from the field of veterinary medicine regarding kosher slaughter. All of these statements, accompanied by the authors' names and affiliations, agreed that shechita was no more - and was perhaps even less - painful to the animal than conventional slaughter. There is no indication in Utlätanden öfver det judiska rituella slagtandet: öfversatt från tyskan as to who it was commissioned by; it appeared in $1898 .^{269}$

269 Anonymous, Utlåtanden öfver det judiska rituella slagtandet: öfversatt från tyskan (Stockholm: Isaac Marcus' Boktryckeri-aktiebolag, 1889). 